\title{
MolNÁR ILDIKó*
}

\section{IRODALOMTÖRTÉNET-ÍRÁS ÉS IDEOLÓGIA ERDÉLYBEN 1918-1964 KÖZÖTT}

\author{
„A szórvány nem a saját területén él, és reménytelenül keresi saját azonosságát”
}

(Belting 2003, 73) ${ }^{1}$

Kulcsszavak: erdélyi tudományosság, erdélyi irodalomtörténet-irás, tudósi életmúvek

Az 1918-1944 közötti időszak az erdélyi irodalomtörténet-írásban a helykeresés és öndefiníciós kérdések talán legtermékenyebb időszaka volt. A „magyar irodalom Erdélyben” gondolata és nem erdélyi vagy romániai magyar irodalom Jancsó Elemérnek mint erdélyi irodalomtörténésznek azt az irodalomfelfogását tükrözte, hogy az erdélyi irodalmat az összmagyar irodalom egyik provinciális elágazásaként kezelte, tehát az egy nemzet egy irodalom eszményét vallotta mindvégig. Az önmagáért való irodalomfelfogást nem tartotta kielégítőnek, mert az irodalmat a társadalom szempontjából is értékesnek akarta tudni, ezt az értéket pedig szerinte az irodalom akkor tudja hozni, ha képes egy közösség problémáinak felismerésére. Jancsó Elemér a transzszilvanizmus ideológiáját kritizálta, azt vallotta: „Ne csináljatok Erdélyből szentséget, de szeressétek úgy, mint ahogy szeretnünk kell azt a földet, ahol az élet élni kényszerít [...]", ${ }^{2}$ helyette európai kitekintést és egyetemességet javasolt, a magyar nemzeti irodalom egységének gondolata mellett foglalt állást. Az erdélyi felvilágosodással kapcsolatos tudományos tevékenysége, majd az általa szerkesztett és útjára indított Erdélyi Ritkaságok forráskiadvány-sorozatának minden egyes kötete a magyar nyelv, a magyar kultúra létjogosultságának egymás mellé állított dokumentumait jelentette Erdélyben. A Trianon előtti területek magyarságának a „közös ősére”, az azonos történelmi élményre apellál abban a reményben, hogy az erdélyi irodalom a hatalmi és területi átrendeződések árán sem kívánja a maga történetét a magyar irodalom történetétől függetleníteni.

Amikor a Jancsó Elemér-életmű feldolgozására vállalkoztam, kérdésként merült föl, hogy hogyan lehetne azt a hatalmas tudósi életművet a lehető legemberibb módon megközelíteni úgy, hogy közben munkásságának valós értékeit a későbbi kutatók felismerjék és tudatosabban nyúljanak azokhoz a szövegekhez, kutatási területekhez, amelyekre Jancsó Elemér írásaiban gyakran fölhívta a figyelmet, amelyet ő is múvelt.

\footnotetext{
* Molnár Ildikó (1981), tanár, Aszódi Evangélikus Petőfi Gimnázium és Kollégium. E-mail: ildikomolnar32@gmail.com.

1 Szegedy-Maszán Mihály: Előszó = A magyar irodalom történetei. A kezdetektöl 1800-ig. Második javított kiadás. Szerk. Jan Kovits László-Orlovszky Géza. Gondolat, Bp., 2008. 16.

2 JAncsó Elemér: Kortársaim. Kriterion, Buk., 1976.26.
} 
A másik ilyen fontos kérdéskör - és ez inkább tudománytörténeti jellegü - arra vonatkozik, hogy befolyásolta-e és ha igen mennyiben és milyen módon az erdélyi irodalomtörténetírásra, különös tekintettel a felvilágosodás korszakára vonatkozó kutatásokat az 1918 utáni hatalmi átrendeződés. Hogyan mutatkozik meg egy életmüben a hatalmi kényszerhez való alkalmazkodás és a magyar irodalom, a magyarság, az anyanyelv védelme, annak legitimációja?

Jelen tanulmány kiindulópontját az erdélyi tudományosság történetének irodalomtörténet-írásra vonatkozó kérdései adják. A tudománytörténet (esetünkben az irodalomtörténetírás) az egyes tudósi életmúveken keresztül való megközelítése sajátos módon értelmezi a korszakkutatásokat, a tudósi élettörténetének feltárásán keresztül az emlékezés kultúrájának sajátos vetületét olvashatjuk.

Jancsó Elemér erdélyi tudós, irodalomtörténész, egyetemi tanár életművén keresztül vizsgálom az irodalomtudomány intézményeit Kolozsváron 1919-1969 között, majd az erdélyi magyar irodalomtörténet-írás hagyományait, az ideológia szerepét az irodalomtörténet-írásban és irodalomoktatásban.

Azt a kérdéskört, hogy befolyásolta-e az erdélyi felvilágosodáskutatásokat az 1918-as hatalmi átrendeződés, valamint hogy mindez hogyan mutatkozik meg egy életmúben, az ideológiai nézőpontok bevonásával kell vizsgálnunk. Az általam kijelölt 1919-1969 közötti korszak erdélyi irodalomtörténet-írásának vizsgálata során az ideológiai nézőpontok bevonását a kutatásba azért tartom indokoltnak, mert a magyarság történetében egy olyan konfliktushelyzet alakult ki a trianoni trauma következtében, amely hosszú időn keresztül meghatározta az erdélyi társadalom magatartását. Az erdélyi magyar társadalomnak egy nagyon komoly mentalitásváltásra kellett megoldásokat találnia, és az erre adott lehetséges válaszok egyikeként értelmezhetőek a két világháború közötti erdélyi irodalmat meghatározó nemzedéki fellépések is. Az Erdélyben maradt értelmiség feladata lett a nemzeti identitás újragondolása, esetlegesen valami teljesen új kialakítása a politikailag adott társadalmi térben. Ez az új identitás a magyar nemzethez való viszonyt úgy kellett, hogy meghatározza, hogy a közös politikai jelent a román államhatalom keretei adták. Az adott történelmi helyzetben megnőtt a csoport-hovatartozások, az identitás meghatározásának jelentősége, és átszőtte az erdélyi magyarság magán- és társadalmi életének minden területét.

Jancsó Elemér az erdélyi magyar tudományos élet ügyéről való diskurzust folyamatosan napirenden tartotta a két világháború közötti erdélyi sajtóban, egészen haláláig, az erdélyi magyarság sorskérdése egyéni kötelezettségként jelentkezett nála. Munkásságában az intézmények történetének a kutatása a tudományosság erdélyi múhelyeinek történeti távlatait alapozták meg, az erdélyi felvilágosodás korszakkutatásait az európai felvilágosodással olvashatjuk párhuzamban. Az erdélyi felvilágosodás fokmérőjének nála az európai felvilágosodás bizonyul. A Független Újság hasábjain cikksorozatban foglalkozik összegző jelleggel az erdélyi magyar tudományos élet 1919-1939 közötti korszakával³ . Jancsó úgy véli, hogy a kultúra intézményesítésének vágya hozta létre egykor a gyulafehérvári Batthyány Könyvtárat, a marosvásárhelyi Teleki Tékát és a szászok büszkeségét: a szebeni Brukenthal Múzeumot. Mindhárom intézményt a nyugat-európai felvilágosodás erdélyi lenyomataként értelmezi. Érdemesnek tartom kiemelni, hogy amikor Aranka György Erdélyi Magyar Nyelvmúvelő Társaságáról

3 Jancsó Elemér: Az erdélyi magyar tudományos élet húsz éve (1919-1939.) Független Újság VII(1940). 1. sz. (jan. 5.) 
és Kéziratkiadó Társulatáról mint tudományos intézményekről ír, vagy az Erdélyi Múzeumról mint a nemzeti műveltséget szolgáló intézményről, akkor hangsúlyozza, hogy ezen intézmények feladataik betöltése során a „békés és védekező nemzeti érzés fellegvárai”, nem egy másik nemzet ellenében létrejött szervezetek, az erdélyi magyar tudományosság múltját nem szennyezte be a másik nemzet iránti elfogultság vagy sovinizmus, hanem európai igények hozták létre”. ${ }^{4}$ Arankát Jancsó Elemér szerint Bölöni Farkas Sándor követi mint egyszemélyes intézmény, a nyugati demokráciák erdélyi nagykövete, aki Döbrentein keresztül ismerkedik meg Kazinczyval.

Jancsó Elemérről az életében megjelent talán első olyan méltatás, amely figyelemre méltó, 1943-ban íródott. Walter Gyula az Erdélyi Szemle 1943/3. számában a lap Erdélyi arcképek rovatában a publikáció dátumát megelőző 22 évnyi idegen megszállás alatti Erdély tudományos életét összegezve Dr. Jancsó Elemér tudósi tevékenységére irányítja a figyelmet. Ennek okát abban nevezi meg, hogy a tulajdonképpeni fiatal nemzedéket 1943-ban Szabó T. Attila és Dr. Jancsó Elemér képviselik, de irodalomtörténészként Jancsó Elemér nevét említi. A cikk iránti érdeklődésemet az vezérelte, hogy hol jelöli ki Jancsó Elemér helyét az irodalomtörténész-nemzedékek sorában, illetve az erdélyi tudományosság, ezen belül az erdélyi irodalomtörténet helyzetét hogyan értékeli.

„Az erdélyi tudomány képviselői az EME körül tömörültek: Balogh Artur, Bíró Venczel, Tavaszy Sándor, Boga Alajos, György Lajos, Kristóf György, Balogh Ernő, Bányai János, K. Sebestyén József, Kelemen Lajos idősebb nemzedék mellett Szabó T. Attila és Jancsó Elemér képviselik a fiatal nemzedéket. De ott vannak még a Délerdélyben rekedt Vita Zsigmond, Debreczy Sándor, Kiss Pál, Oberding József, Bíró Sándor, Reischel Artur, Venczel József. Az Erdélyi Tudományos Intézet létrejöttével és az egyetem hazatérésével e névsor tovább bővül: Entz Géza, Makkai László, Bíró Béla, Hantos Gyula, Lakatos István, Mikó Imre, László Gyula, Kol Erzsébet, Bálint Zoltán, Baráth Tibor, Szilágyi Lóránt.”6

Walter Gyula, miután ismerteti Jancsó Elemér addigi munkásságát, arra inti, hogy csökkentse érdeklődési körét a minőségi javulás érdekében, és a sok apró részletmunka elvégzése után egy nagyobb szintézis formájában adjon számot tudományos tevékenységéről.

„Legyen mestere Beöthy, Riedl, Péterffy, Pintér és társainak szelleme, hogy mindenik múve új színekkel gazdagítsa a magyar irodalomtörténetet és az egyetemes irodalmat." 7

Jancsó Elemér irodalomtörténészi tevékenysége során az erdélyiség kérdésköre mindig középpontban van. Egyéni elkötelezettségének, hivatásának tartotta az egyetemi képzésben a

4 Uo.

5 Walter Gyula: Erdélyi arcképek. Erdélyi Szemle 28(1943). 3. sz. 18.

6 Uo.

7 Uo. 
tudós-tanár típus eszményét, ezen túlmenően a sajátosan erdélyi témák feldolgozását, legyen az kortárs erdélyi irodalom vagy korábbi korszakokra vonatkozó tudományos kutatás. Az általa irányított államvizsga-dolgozatok szerzői köréből került ki a későbbi tanár- vagy tudósnemzedék nagy része is. Diákjainak tudatosan próbált olyan kutatási témajavaslatokat adni, amelyekben a speciálisan erdélyi vonatkozású anyagok feldolgozását helyezte előtérbe, mert nagy hiányosságának tartotta az erdélyi irodalomtörténet-írás, az erdélyi tudományosság területén a levéltári anyag még ismeretlen kéziratainak nyilvánosságra hozatalát. 1926-ban készült doktori értekezése is - Erdélyi jelleg a magyar irodalomban - ezt a sajátosan erdélyi jelleget dolgozza fel. Kutatásainak elsődleges szempontja tehát az erdélyi jellegű anyag feldolgozása, feldolgoztatása.

„Mi az erdélyiség? Hol és mikor nyilatkozik meg először Erdély sajátos szelleme?” - teszi fel a konkrét kérdést Jancsó Elemér 1940. június 30-án a Keleti Újság vasárnapi számában. Jancsó Elemér hitt abban, hogy az erdélyiség, az erdélyi szellem létezik, ennek történelmi bizonyítékait kutatja az egyes történelmi korok, személyiségek életmúvén keresztül.

„A szellemi élet múltja éppoly rejtélyes, mint az a ködbevesző jövő, amely felé egymással ellentétes irányú utak visznek. Az emberi lelket a magával hozott természeti tulajdonságokon kívül tájak és korok formálják ki. Az erdélyi szellem sem más, mint az erdélyi hegyek és emberek találkozása a történeti időkkel. Az a lelki jegy pedig, amit az író és tudós észrevesz a múlt idők arcán csak jelkép, alig megismerhető tények szimbóluma. És mégis az emberi megismerés tökéletlen volta miatt kénytelenek vagyunk ilyen jelképeken gondolkozni, mert ezek így is emlékeket, emberi arcokat, kettétört szándékokat idéznek fel. Ha Erdély több mint félezer éves ősi magyar műveltségét nézzük, akkor úgy látjuk, hogy különösen három lelki magatartás jellemzi szellemi életét. Az egyik a történeti tudat ${ }^{9}$, a másik az Európába kitekintő akarat, a harmadik népi szándékainak időnként fel-feltörố vágya. Természetesen ezt a három lelki vonást színezik a korok, a megnyilatkozási formák és az írói egyéniségek egyaránt. A Keletről hozott népi műveltség ősi formái Erdélyben élnek legtovább. Nem véletlen, hogy a rovásírás éppen Erdélyben maradt fenn, ott, ahol a virágénekek, népdalok és balladák leggazdagabb fái virágoztak. És hiába nyesegették magyar nyelvü, de idegen eredetű és lelkű kezek ezeket az ősi mesefákat, a kettétört törzsből újból és még erősebben hajtott ki az elnyomott népi lélek zöld lombja”. ${ }^{10}$

Jancsó Elemér tudósi magatartásának az erdélyiség mellett egy másik nagy vesszőparipája az európaiság. Nemcsak saját európai utazásai, párizsi tanulmányai igazolják ezt, hanem kutatásai is ezeken a tudatosan szervezett irányvonalak mentén folynak. A nyugatjárók életművének, munkásságának a feltárása Jancsó Elemér kutatói tevékenységébe programként illeszkedik, hogy általuk egyben az erdélyi szellem európaiságát is hangsúlyozzák.

\footnotetext{
8 Jancsó Elemér: Erdély régi magyar múveltsége. Keleti Újság Vasárnapja 1940. június 30.

9 Kiemelések tőlem: M. I.

10 Uo.
} 
„Az európaiság régi erdélyi hagyományokra tekinthet vissza. A 700 éves Sorbonne legelső tanulói között már találunk erdélyi magyart, de a nyugatjárók szakadatlan sorát, amely Apáczain át Adyig tart, sem a mostoha körülmények, sem más külső tényezők nem szakítják meg. Erdély minden időben tárt kapukat nyitott a Nyugat elôtt és ezeken a kapukon át beengedte a nagy szellemi áramlatok épitő és alakító eszméit." ${ }^{11}$

Az erdélyi szellem és európaiság mellett az erdélyi tudós másik ismertető jegye a történelmi tudat, egy nagyon határozott identitástudat, amely a tudósi életmúben összekapcsolódik a hivatástudattal is. „A történeti tudatnak szintén mély és régi idókbe nyúló gyökerei vannak Erdélyben. A kápolnai unió nem csupán jövőt építő szövetkezés, de egyúttal hivatástudat is. A történelmi érzék természetszerúleg a kiváltságos osztályokban erős és ezek hagyományaként száll az utókorra, tör be a tudományba és irodalomba és válik a sajátos erdélyi életszemlélet egyik alapelemévé". ${ }^{12}$

Jancsó Elemér a népi szellem, az európai kitekintés és a történeti tudat hármasságát „szent örökségként" vezeti végig Erdély történelmén. Bethlen Gábort az erdélyi szellem és életakarat európai szimbólumaként idézi, mint Erdély politikai és szellemi egységének megerősítőjét. „Az európai szellem és az erdélyi sorsvállalás jelképe Apáczai Csere János. Mialatt nyugati eszmékkel gazdagította szúkebb hazáját, ugyanakkor erdélyi akadémia felállításáról is álmodozik és az anyanyelvi oktatás elvét hirdeti”. ${ }^{13}$

Jancsó Elemér a történeti szellem képviseletét a sajátosan gazdag erdélyi emlékirat-irodalommal példázza. Mindszenthi Gábor 1540-ben megjelent naplójától kezdve Kemény János fejedelem önéletírásában, Szalárdi János krónikájában, Cserei Mihály, Apor Péter és Bethlen Miklós visszaemlékezéseiben a történelmi tudat írott emlékeit látja, olyan írott emlékeket, amelyek valóságát Erdély nagy fejedelmei bizonyították. Az erdélyi lélek és a népi szellem sajátos példája Mikes székely nyelven írott levelei, az a sajátosan erdélyi gondolkodás, ami a levelekben megmutatkozik hagyománytisztelő szellemet idéz. Bod Péterben és Apácai Csere Jánosban látja az erdélyi tudósnemzedékek nemcsak első láncszemeit, de az enciklopédikus erdélyi tudósjellem mintaadóit is. A magyar akadémia gondolatának felvetői követókre találnak tudatos erdélyi programjukkal Batthyány püspök, Aranka György, Döbrentei Gábor, Bölöni Farkas Sándor és gróf Mikó Imre személyében. Az erdélyi felvilágosodás korában megmutatkozó történeti tudatot a Kéziratkiadó Társasággal jelképezi, a korban megmutatkozó európai szellemet Erdély francia múveltségú íróiban látja.

\section{AZ ELSŐ VILÁGHÁBORÚ ELŐTTI ERDÉLYI MAGYAR TUDOMÁNYOSSÁG}

Az első világháború előtti korszak irodalomtörténeti tárgyú kutatási feladatait a kolozsvári egyetem, irodalmi társaságok és folyóiratok látták el, valamint erdélyi tárgyú tudományos szakkönyvek. Az 1867 utáni erdélyi tudományos élet fő hibáját Jancsó Elemér abban látja,

11 Uo.

12 Uo.

13 Uo. 
hogy a magyar tudományegyetem, a professzorok nagy része nem erdélyi tudományos kérdések feldolgozására szentelte idejét és tudását, hanem a már idegen nyelveken félig készen kapott problémák magyarul való feldolgozásával elégedett meg. Jancsó Elemér szerint létezett valamiféle vak és ostoba közöny, amelynek tulajdonítható az, hogy az Erdélyi MúzeumEgyesület gazdag levéltára a 20. század közepén is még feldolgozatlan volt, pedig ez az anyag közel fél évszázadon át minden erdélyi és főként kolozsvári kutató rendelkezésére állt. Tudósi hivatásának tekinti a vidéki levéltárak kéziratos anyagainak feldolgozását is, Erdély jövendőbeli tudósnemzedékeitől várja ezen értékes tudományos anyagok feltárását. Jancsó Elemér szerint az nem lehet, hogy ezek a magyar irodalom és történelem múltját magukban rejtő poros és elfakult írások feledésbe merüljenek. ${ }^{14}$

Ezek okán Jancsó Elemér az erdélyi magyar tudósnemzedék kinevelését hivatásának tekinti, akárcsak elődei, György Lajos vagy Kristóf György. Egyetemi tanári tevékenységének ezért kulcsfontosságú részét az államvizsga-dolgozatok témafeldolgozásai jelentették, valamint a levéltári kéziratos anyag feldolgozása, kiadása. Ha áttekintjük Jancsó Elemér forrásközléseit, akkor Bod Péter, Aranka György és az Erdélyi Magyar Nyelvművelő Társaság iratai, Döbrentei Gábor, Bölöni Farkas Sándor, Gyarmathy Sámuel, Kőrösi Csoma Sándor nevei jelzik forrásközlő tevékenységének folyamatosságát.

Az erdélyi tudományosság történetében is fordulópontot jelentett az 1918-as fordulat, a többségiből hirtelen kisebbségivé vált erdélyi magyarság identitását, saját hivatástudatát Jancsó szerint még 1940-ben sem tudta teljesen tisztázni, és ezen identitásválságnak lehetett oka az is, hogy szembekerült egymással nemcsak a többségi és kisebbségi nemzet, hanem a válsághelyzetből adódóan bizonyos csoportidentitások is szembekerültek egymással. Így szembekerült Erdélyben az irodalmi és tudományos élet. Az írók és tudósok egymással való szembekerülése nemcsak elvi harcokat jelentett, hanem olyan személyi ellentétek kiélesedését is magával hozta, amelyek kárára voltak mind az irodalomnak, mind a tudományosságnak egyaránt. „Tudósaink az irodalommal szemben túlzott igényekkel léptek fel, a kezdő irodalmat megérdemlő erkölcsi támogatás helyett a kritika legmagasabb mértékét próbálták alkalmazni. Természetesen ezt a „kritikai hadjáratot” az írók beteges érzékenysége visszautasította és még az enyhébb bírálatot sem türte el, ha az a „tudósok” oldaláról jött”. ${ }^{15}$ Igy egymás létjogosultságát hosszú időn keresztül kölcsönösen kétségbe vonták.

A magyar tudományosság történetét az első világháború után Jancsó Elemér három kisebb korszakra tagolja: az első körülbelül 1926-ig tart, és a „próbálkozások korának” nevezi, a második korszakot a „csendes erőgyüjtés korának”, a harmadikat a fellendülés korának nevezi.

A Jancsó által kijelölt első korszakot a kolozsvári egyetem átvétele körüli viták határozzák meg túlnyomórészt. Köztudott, hogy az egykori Ferenc József Tudományegyetem tanárai szinte kivétel nélkül elhagyták állásukat és Magyarországra telepedtek át. A tudományos élet fórumait a Pásztortúz, a Zord Idők, a Napkelet, az Erdélyi Szemle képviselték. A magyar irodalomtudományt Erdélyben az Erdélyi Irodalmi Szemle képviselte ebben az időben, melyet kezdetben Borbély István, majd György Lajos szerkesztettek. Említeni kell még a háromnyelvű

14 Jancsó Elemér: Az erdélyi magyar tudomány húsz éve. I. (1919-1939). Az Ország Útja 4(1940). 1. sz. (jan.) 7 .

15 Uo. 8 . 
Cultura nevü folyóiratot, melyet a kolozsvári egyetem tanárai szerkesztettek három nyelven. A lap magyar részét Kristóf György szerkesztette nemzeti konzervatív szellemben.

A második korszakban fellendül az irodalmi élet, hiszen Helikon és az Erdélyi Szépmíves Céb intézményes formát biztosít a kisebbségi irodalomnak. Rass Károly irodalomtörténésztől származik a háború után az erdélyi Magyar Tudományos Akadémia létesítésének a gondolata, de hamar lekerült a napirendről, hiszen az erdélyi tudományosság még a régi intézményeinek a fenntartásával is küzdött. Úgy tünik, hogy az erdélyi irodalom fellendülése az erdélyi tudományosság tendenciáival ellentétes irányt mutat ${ }^{16}$. Az Erdélyi Irodalmi Szemle beleolvad az újból meginduló, nagy hagyományokkal rendelkezô Erdélyi Múzeumba. Az Erdélyi Múzeum szerkesztői feladatait György Lajos látta el, csakhamar az erdélyi magyar tudományosság mérvadó lapja lett.

E második korszakban indul a Korunk is, 1926-ban, Erdély egyetlen társadalomtudományi folyóirata. „Megindítója: Dienes Jenő az akkoriban megszűnt Napkelet helyébe akart az akkor még Erdélyben nagyon erôs polgári radikális rétegek számára orgánumot teremteni”. ${ }^{17}$

A tudományosság intézményei Erdélyben ekkor a Ferdinánd Egyetem, az Erdélyi Múzeum-Egyesület és az Erdélyi Tudományos Intézet voltak. E három intézmény köré szerveződnek még a tudományosság fórumai, a különböző szaktudományos folyóiratok. A magyar tudomány fórumát eleinte Borbély István, majd György Lajos által szerkesztett Erdélyi Irodalmi Szemle biztosította. Az erdélyi magyar tudományos élet helyzetéről Jancsó Elemér a Független Újság 1940. januári számaiban egy négyrészes cikksorozatban számol be. A tudományosság általa megjelölt harmadik korszaka fellendülést mutat, a tudományos élet újjászerveződésének tevékeny éveit jelöli meg. A legfontosabb szerepet az Erdélyi Múzeum-Egyesület tölti be, hiszen nemcsak a lap kiadásával, hanem az EME vándorgyúléseivel országszerte hozzájárult a tudományos élet működéséhez. A vándorgyúlésekről évkönyvek készültek, amelyek a vándorgyülések előadásainak színvonalas előadásait tartalmazták.

Az Erdélyi Múzeum-Egyesület mellett a tudományosság másik két fóruma volt az Erdélyi Fiatalok és a Hitel című folyóirat, amelyek főként a fiatal nemzedéket tömörítő lapok voltak. Jancsó szerint a kisebbségi tudományos életbe ${ }^{18}$ a felekezeti szempontok behatolása jelentős, hiszen a vallásnak a kisebbségi élet újjászervezésében nagy szerepe volt. A lapszervezésben a felekezetiség meghatározó volt, így említi a kolozsvári Hirnök és az aradi Vasárnap mint katolikus szépirodalmi és vallásos folyóiratok szerepét. Az Erdélyi Tudósitó és az Erdélyi Iskola szintén katolikus célokat szolgáltak, egyben a kisebbségi nevelésügyet, olyan szerkesztőkkel, mint György Lajos és Márton Áron. Az Erdélyi Katolikus Akadémia a katolikus tudományos törekvések szintetizálására jött létre. Ugyanígy a protestáns vonalon is megnevezhetjük a tudományosság fórumaiként a Kiáltó Szó, az Ut, az Ifjú Erdély, a Református Szemle, a Református Család, majd a katolikus mintájára létrejött Károli Gáspár Társaságot. Az unitáriusok tudományos tevékenységét a jól ismert Keresztény Magvetó képviselte, valamint az Unitárius Irodalmi Társaság. Az intézmények és szaklapok mellett jelentős szerepük volt azonban olyan

16 Kiemelés tőlem: $M$. I.

17 Jancsó Elemér: A magyar tudományos élet Erdélyben 1918-1940. Kisebbségi Körlevél V(1941). jan. 26-34.

18 Uó: Az erdélyi magyar tudományos élet húsz éve (1919-1939.) Független Újság VII(1940). 1. sz. (jan.) 5 . 
meghatározó egyéniségű tudósoknak az irodalomtörténet tudományterületén, mint Széchy Károly, Böhm Károly filozófus, Kristóf György, György Lajos vagy Jancsó Elemér, akiknek munkássága köré tudós nemzedékek sorakoztak föl.

\section{IRODALOMTÖRTÉNET-ÍRÁS ERDÉLYBEN 1918-1940}

\section{Az irodalomtörténet-írás módszertana a Jancsó életmúben az 1930-as évek közepén}

A kérdéskör vizsgálatát Jancsó Elemér: Irodalom és társadalom ${ }^{19}$ című tanulmánya alapján vizsgáltam, különös tekintettel arra, hogy milyen álláspontot alakított ki az előtte járó irodalomtörténész-nemzedékekkel, illetve a kortárs irodalommal kapcsolatban. Jancsó írásából kiderül, hogy nem célja az előtte járó nemzedékek irodalomtörténet-írását kritizálni, elismeri az általuk teremtett értékeket, ugyanakkor felhívja a figyelmet arra, hogy nem elégedhet meg a tudományosság a nagy egyéniségek kiemelésének fóhangsúlyával, továbbá meg kell teremteni a folytonosságot az irodalomtörténet-írásban a kortárs irodalom irányába is. Az irodalomtörténet-írás nem állhat meg önmaga előtt néhány évtizeddel (1934-ben aktuálisan Madáchnál, Herceghnél, Mikszáthnál és Szabolcska Mihálynál), a kortárs irodalom értékelését is az irodalomtörténet-írás részévé kell tenni, nem lehet megelégedni azzal az ígérettel, hogy csak néhány évtized távlatából értékelhető a kortárs irodalom. Érve a következő: „[...] mi értelme van a mai életnek, legyen az szellemi, vagy társadalmi, ha saját életünkből ki akarjuk azt zárni, ellene, vagy mellette nem foglalunk állást?”. ${ }^{20} \mathrm{Ez}$ az új módszer nem az „örök értékek”-re való rámutatásban nyilvánulna meg, tehát nem az esztétikai ítéletalkotást végezné el, hanem leírná azokat az új szempontokat az értelmezésben, amelyekre csak a jelenben lehet rámutatni, elvégezni. Az irodalomszociológia mint a kor legjellegzetesebb tudománya az a módszer lenne, amellyel leírhatók olyan új területek az irodalomtudományban, mint például az irodalom szerepe a társadalomban. Jancsó szerint az irodalomszociológia módszere „leírja az író jellemét, társadalmi adottságait, művei eredetét, hatását, de sohasem az egyén kiemelésére és művének esztétizálására fekteti csupán a súlyt, hanem e mű kézzel fogható, vagy legalábbis felmérhető hatásaira. Nemcsak írókat vizsgál, hanem folyamatokat is, amik írókon és műveken át élnek és hatnak". ${ }^{21}$

Jancsó Elemér irodalomtörténet-írásról vallott nézetei az évek során kontúrozódnak. 1940-ben úgy látja, hogy az erdélyi irodalom rendeltetése a történeti tudat, a népi szellem és az európaiság hármasságában valósítható meg a továbbiakban is. ${ }^{22} \mathrm{~A}$ legjellegzetesebb nemzeti tudományoknak nevezi Jancsó a történettudományt, az irodalom- és művészettörténetet. Jancsó Elemér saját irodalomtörténészi munkásságát a fiatalabb nemzedék körében jelöli ki. Idetartozik Vita Zsigmond, Pogány Albert, Reischel Arthur, Pellion Ervin, Debreczy Sándor, Sántha Alajos, Veégh Sándor, Vörös István, Jancsó Elemér és Kovács József. Az idősebb nemzedéken a háború előtt jelentkező irodalomtörténészeket érti, Pálfi Márton, Kántor Lajos,

19 Uő: Irodalom és társadalom. Erdélyi Fiatalok V(1934). 21-24.

20 Uo.

21 Uo.

22 Uő: Az erdélyi magyar tudományos élet. Tudósok, folyóiratok, egyesületek a tudományosság szolgálatában. A jövő feladatai. Független Újság III(1940). 3. sz. 
Rajka László, Bitai Árpád, Császár Károly, Rass Károly mellett Kristóf Györgyöt, Borbély Istvánt és György Lajost emeli ki.

\section{Múltszemlélet, felekezetiség és tudományosság}

„A történettudománnyal részletesebben azért foglalkoztunk, mert meggyőződésünk szerint kisebbségi életünkben igazi tudósfeladatot az végez, aki tudományága erdélyi problémáját dolgozza fel,- de erdélyi jellegü feladat csaknem minden tudomány mezején bőven található. [...]”. A tudományos könyvkiadástól azt várja, hogy ezen a területen ne a közönségsiker, hanem a tiszta tudomány által parancsolt szempontok jöjjenek csak számításba. A kisebbségi tudományosság föllendülését csak akkor reméli, ha a magyarság fölismeri, hogy a tudomány éppúgy lét- és életkérdés, mint az iskola vagy a gazdasági jólét.”Jancsó Elemér már 1937-ben foglalkozik a magyar múltszemlélettel, amikor a Kiáltó Szó 1937. márciusi számában ismerteti a Szekfü Gyula és Mályusz Elemér közt kialakult vitát a nemzeti múlt „átértékeléséről”. ${ }^{23}$ „Szekfú álláspontja tehát világosan az, hogy az „új” magyar történetszemlélettel igazolja a mai magyar katolicizmus előretörését és annak múltját a „magyar renaissance-, felvilágosodás-, liberalizmus" fölé helyezze". ${ }^{24}$ Mályusz Elemér elismeri a munka sikerességét, ső́t nem is tartja hatásosnak ezzel szemben egy protestáns történetírást adni, viszont olyan területet keres a protestáns történetírás számára, amely nem a katolikus történetírással szemben íródik, hanem a maga hagyományaiból kiindulva képezi a sajátosan protestáns történetírást, és ez a terület a magyar népiség történetének a feltárása. Jancsó Elemér Mályusz tanulmányának a lényegét abban látja, hogy nem szabad „a népiségtörténet előterébe a protestáns szempontokat" helyezni.

Jancsó álláspontja a múltszemlélettel kapcsolatban tudományosság és felekezetiség, azaz a felekezetiségnek nem szabad a tudományosság kritériumait megelőznie. Nem a felekezetiség tagadásáról van szó, hanem az erdélyi tudományos élet egységkeresését kell látnunk, de nem egyfajta szocialista egységkeresést, hanem inkább erőkoncentrációt az erdélyi magyar tudományos élet irányába. Abban a korban, amikor egy tudományterület, jelen esetben az irodalomtörténet-írás alapjait kívánják lerakni tudósaink Erdély megváltozott történelmi viszonyai után, logikus, hogy valami empirikus érvet keresnek önigazolásukra.

\section{IDEOLÓGIA ÉS IRODALOMTÖRTÉNET-ÍRÁS}

Az 1945-ben megalakult Bolyai Tudományegyetem magyar irodalomtörténeti intézetéhez György Lajost és Jancsó Elemért nevezték ki, György Lajost prorektor minőségben, Jancsó Elemért a Bölcsészeti Kar dékánjának. Jancsó Elemér 1945-1949 között modern irodalmat ad elő, a régi irodalmat pedig György Lajos tanította. 1945-től kezdődően a „szocializmus építése” és a „kulturális forradalom” átírta a magyar irodalomtörténet oktatását is. Háttérbe

23 Mályusz Elemér történészprofesszor, aki a Budapesti Szemle 1936-os évfolyamában a Magyar barokk, magyar renaissance című tanulmányában cáfolja Szekfü Gyula ismert „középkor-, barokk-, romanticizmus, neoromantizizmus” szemben „renaissance-, felvilágosodás-, liberalizmus” álláspontot.

24 Jancsó Elemér: Kiáltó Szó. 1937.3. sz. 
szorultak a filológiai kutatások és a magyar irodalomtörténeti hagyomány teljes átértékelését követelte meg a politikai hatalom. Ez az átértékelés a marxista szempontokat követelte, amelynek következményeként új középiskolai tankönyvek és szöveggyüjtemények váltak szükségessé. Jancsó Elemér az Utunk első évfolyamában, 1946-ban A megújhodó magyar irodalomszemlélett címmel számol be erről az „új” irodalomszemléletről. ${ }^{26}$

Az irodalomtörténet tanítása és a tankönyvkérdés nem öncélú tudományos kérdés, hiszen meghatározta az egész művelődéspolitikát. Az irodalomszemlélet és irodalmi nevelés korszerűsítését azért veti fel, mert a rendelkezésre álló tankönyvek vagy elfogytak, vagy nem íródtak újak, és érdemük abban a negatívumban állt, hogy hiányoztak belőlük a soviniszta reakciós múltszemléletet alátámasztó olvasmányok. ${ }^{27}$

Olyan új tankönyvek szükségét látja 1946-ban, amely a „feltörő népi demokráciát” szolgálja. „Az irodalomszociológia eddig elért eredményei, az utolsó negyedszázad gazdag részlettanulmányai, a modern tudományok sok irányba ihlető elindításai nyomán ma új szellemű, haladást előmozdító tankönyvek íródhatnának meg a régi valóságkendőző, vagy az új, félig sikerült iskolai könyvek helyett. Természetesen nálunk Erdélyben ennek az új irodalmi nevelésnek a sajátos erdélyi hagyományokra és az élő irodalomra is tekintettel kell lennie". 28

Mint ahogyan sok más erdélyi értelmiségi, Jancsó Elemér ekkor még bízott abban a hamis képzetben, hogy: „A második világháború a Szovjet-hadsereg és a szabadságszerető népek győzelmével megteremtette a dunai népek végleges kibékülésének lehetőségét, a magyarság számára szabaddá tette népi erőinek a demokrácia irányítása alatti kibontakozását”. ${ }^{29} \mathrm{Az}$ erdélyi magyarság önvédelmét a kisebbségi demokrácia és a szellemi erők összefogásában látták megvalósíthatónak, ehhez kapcsolhatók Jancsó Elemér Bölöni Farkas Sándor naplóinak kiadása, akit Jancsó a demokrácia erdélyi nagyköveteként ábrázol, mint székely nemest a demokrácia szolgálatában. Csakhogy ez a demokráciafogalom a nyugati demokráciák hagyományait követi, és nem egy szovjet típusú demokráciaelképzelést. Ezek a nyugati útleírások megismertették az erdélyi társadalmat más országok hagyományaival, társadalmi berendezkedéseivel, szokásaival és az erdélyi viszonyokra való alkalmazhatóságát, hasznosságát jelentették, mint látjuk, nemcsak a maguk korában. Jancsó Elemér és eszmetársai, mint Abafáy Gusztáv, Dániel Antal, Heszke Béla, Szemlér Ferenc, Balogh Edgár, Méliusz József, Szabédi László stb. baloldali gondolkodókként hangoztatták egy nemzeti közösség, a kisebbségbe jutott erdélyi magyarság törekvéseit és egy „demokratikus szocializmus” eszményben látták a diktatúrák elleni küzdelmet. Az erdélyi magyar baloldal és a magyarországi baloldal 1945 utáni szerepei teljesen másak: „[...] az erdélyi magyarságot éppen baloldali beállítottsága mentette meg attól, hogy a nagyromán nacionalizmus leszámoljon vele. ${ }^{30}$

25 Uő: A megújhodó magyar irodalomszemlélet. Utunk I(1946). 13. sz. 2.

26 De ez még nem az 1948. augusztus 3-tól érvénybe lépő, a tanügyi törvény romániai oktatásügyet szovjet mintára átszabó politikája. Ekkor még Romániában (1945-1948 között) a Groza-kormány „magyarbarátnak” nevezett oktatási autonómiâja él!

27 Uo.

28 Uo.

29 Uő: Az elmúlt száz év mérlege. Utunk II(1947). 7. sz. (márc. 29.) 3.

30 Pomogáts Béla: „Demokratikus szocializmus” és „létezô" diktatúra. Tánczos Gábor emlékkönyv. Kortárs 1998. 8. sz. 25. 
1949-től 1959-ig Jancsó Elemér a felvilágosodás korának irodalomtörténetét adta elő, és nyolc évig a 20. század magyarországi irodalmát. Ebben az időszakban a tanszék tagjai több mint 25 középiskolai tankönyvet és szöveggyưjteményt írtak és szerkesztettek, de ezek mellett egyetemi jegyzeteket is, Jancsó Elemér ekkor készíti el egyetemi jegyzetét, a felvilágosodás korának irodalomtörténetét ${ }^{31}$, melyet 1969-ben adtak ki. 1956 szeptemberétől 1959 februárjáig Jancsó Elemér tanszékvezető professzora a magyar irodalomtörténeti tanszéknek Kolozsváron, majd 1965 szeptemberétől ismét.

Ezek az évek azonban a nem tehermentesek, tragédiák sorozataként is rögzíthetnénk, ami ezekben az években történik. Az irodalomtörténet oktatásának országos jelentőségű feladatot szánnak és ezt programszerüen végre is hajtják: „A magyar irodalomtörténeti katedra feladata abban áll, hogy a RNK magyar egyetemén a magyar irodalom helyes, tudományos kutatásával és jól képzett fiatal tudományos és didaktikai káderek nevelésével járuljon hozzá a formájában nemzeti és tartalmában szocialista kultúra kialakulásához és növekedéséhez országunkban. Első látásra kitűnik, hogy e megtisztelő feladat megoldása az ideológiai éberség és harciasság magas fokát követeli meg. A burzsoá magyar irodalom és annak „tudományos” kutatói át és át voltak hatva a nacionalizmus és kozmopolitizmus minden mérgétől. Az újszellemú irodalomkutatás csakis ezeknek a tudománytalan és ellenséges hatásoknak kíméletlen leleplezésén és leküzdésén keresztül törhet magának utat. A magyar irodalomtörténeti katedra munkatársai közül többen nem voltak tudatában ennek az elemi igazságnak" ${ }^{32}$ Csehi a tanszék munkájának pozitívumait a tankönyvírásban és néhány Utunkban közölt irodalomtörténeti publicisztika elkészítésében látja, legfontosabb dolognak viszont - nem kis iróniával kell hozzátennem - azt, hogy: „E katedráról véglegesen eltűntek a reakció tudatos ügynökei, akik a felszabadulás után még évekig kezükben tartották a Bolyai Egyetem igen fontos szektorait. Például György Lajos, aki megfogadta Horthynak: »őrködni fog, hogy a tudományosság csillogása alatt ne bujjon nemzetrontás, társadalmi mételyezés vagy bármely féktelenség“ és aki jobb ügyhöz méltó következetességgel igyekezett ezt a rendőr ügynöki feladatot a fasiszta rendszer összeomlása után is teljesíteni”. ${ }^{33}$

Mindezekből kitűnik, hogy céltudatosan történik a szovjet mintájú szocializmus (bolsevik típusú kommunizmus) kiépítése, amely az erdélyi magyar értelmiség demokratikus szocializmusával, a népi demokráciát óhajtó „,harmadik utat” jelentette volna.

Érdemes megnéznünk, hogy milyen kritikákat fogalmaz meg a tanszék oktatóival szemben, mekkora szemléletváltást vár el tőlük a rendszer, amit nem is tudnak vagy nem is akarnak teljes mértékben teljesíteni. Faragó Józseffel szemben az a kifogás, hogy a marxizmus-leninizmus klasszikusai és a szovjet tudomány helyett Lukács Györgyhöz és kisebb mértékben Gaál Gáborhoz fordul ideológiai szempontból, sőt, a legnagyobb probléma inkább az, hogy nem építi be saját gondolkodásába ezeket az ideológiákat, mert kritika nélkül teszi ezt, ami Csehi szerint ideológiai zavart okoz. Faragó előadásaival szemben az a kritika fogalmazódik meg,

31 Jancsó Elemér: A magyar irodalom a felvilágosodás korában. Ed. Didactică şi Pedagogică, Buc., 1969.

32 Cseni Gyula: A magyar irodalomtörténeti katedra munkájának megjavitásáért a Bolyai Tudományegyetemen. Utunk V(1950). 9. sz.

33 Uo. 
hogy a pártosság megállapítása helyett csak azt igyekszik megállapítani, hogy „hogyan jött létre a műalkotás?"

A pártosság követelményeinek (kimutatni azt, hogy az egyes szerzők vagy művek milyen társadalmi osztály érdekeit képviselik, és az alapján megítélni, hogy haladó vagy reakciós szerepet játszott korának osztályharcában) Faragó abban sem tesz eleget, hogy a polgári szerzőket idézi elismerő jelzők kíséretében, annak ellenére, hogy előtte bírálta azokat.(!)

Szigeti József - aki a régi magyar irodalomtörténet (1711-ig) előadótanára - ott követ el hibát, hogy nem a szovjet kézikönyvek alapján, hanem Lukács György elméleteit idézi, nem a társadalmi fejlődés mindenütt érvényes törvényszerűségeit és a magyar és kelet-európai népek közös történelmi sorsáról ír, hanem valami magyar sajátságról. Szigeti tehát attól nacionalista Csehi szerint, hogy eltúlozza a szerzetesrendek szerepét, „a kereszténység felvételét nem mint az új társadalmi rendre való áttérés következményét, hanem mint annak okát állítja be."

A sort folytathatnánk. További kritikát kap még Abafáy Gusztáv is kozmopolitizmusa és a komparatisztika eredményeinek felhasználása végett. Jancsó Elemérnek a 20. század magyar irodalma kurzusával kapcsolatban is az a vád, hogy a polgári irodalomtörténet-írás eredményeit használja fel, sőt nem is értékeli azt át. ,Jancsó elvtárs ilyen módon fel sem veszi a harcot a polgári irodalom dekadenciája ellen, hanem ellenkezőleg, »ártatlansági bizonyítványt « állít ki számára." Csehi az egész irodalomtörténeti munkaközösség munkájának hiányosságát látja abban, hogy az előadók nem ismerik és használják a szovjet tudomány eredményeit, legfeljebb Lukács Györgyöt és Gaál Gábort idézik. (!)

\section{A „HALADÓ HAGYOMÁNYOK” ÁPOLÁSÁNAK KÉRDÉSKÖRE}

Az intézményhálózaton keresztül egy szigorúbb ideológiai ellenőrzés gyakorlatának szándéka állt azon kulturális politika mögött, amely új intézmények létrehozását propagálta az 1950es évek elején. Egy ilyen ideológiai trükk volt a haladó hagyományok ápolásának propagandája is. „Félretéve a marxista sémákat, a haladó hagyományok ápolása egyszerűen egy kizáró (magyar) jellegű nemzeti emlékezet újratételezését hozta magával, amely újratételezést egy ideológiai hézag kihasználásával oldottak meg: a „nemzeti” fogalmat a politikailag korrekt „haladás” fogalmával helyettesítették”. ${ }^{34}$ 1951-ben a bukaresti Állami, Irodalmi és Múvészeti Kiadó magyar osztályán Gaál Gábor szerkesztésében „Haladó hagyományaink” címmel sorozatot indított. A felszabadulás utáni első években ugyanis erőteljes kísérlet indult a kommunista ideológusok részéről a magyar történelem nagy alakjainak egy nemzetek fölötti, internacionalista kánonba való beemelésére. A haladó hagyományok ápolása olyan múltértelmezést jelentett, amely a múlt pártos szemléletére nevelt, olyan szemléletre, amely a béke szellemében egy nemzetek fölötti testvériséget, kommunista internacionálét célzott meg. Jancsó Elemér ezen haladó hagyomány megismertetése, elsajátítása terén azt az előfeltételt hangsúlyozza, hogy először meg kell védeni az elkallódástól a marxista értékelés további „alapanyagát”. „Irodalmunk emlékei könyvekből, kéziratokból, levelezésekből állanak. Nagy

34 Stefano Botroni: Sztálin a székelyeknél. A Magyar Autonóm Tartomány története (1952-1960). ProPrint, Csíkszereda, 2008. 131. 
részük alig ismert és csak részben feldolgozott”. ${ }^{35}$ Nem a nagy könyvtárak anyagáról van szó, hanem a kisebb vidéki könyvtárak és magángyüjteményekben lévő kéziratok, irodalmi levelezések, írói relikviák. Egy irodalomtörténeti múzeum felállítását javasolja ezen emlékek őrzési helyéül. Ezt az irodalomtörténeti múzeumot Kolozsváron képzeli el az Akadémia keretében és irodalomtudományi kutatóintézet létesítését is szükségesnek tartja. A múzeum feladata a fellelhető irodalmi anyag összegyüjtése lett volna, a kutatók feladata az anyag folyamatos feldolgozása. Egy évvel később az Utunkban ${ }^{36}$ arról tájékoztat, hogy az Igaz Szó ezen „haladó irodalmi hagyományok" ápolása értelmében egy új rovatot indít az 1955. októberi számtól kezdve Anyag és adat címmel. Mitől óvja a lap szerkesztőségét ezen adatok közlése során? „A haladó hagyományok ápolóinak nagy része vagy kezdő szakember vagy lelkes dilettáns, aki újra felfedezi a puskaport, a szakemberek által már ismert anyagot közöl vagy éppen lelkiismeretlenül pontatlan, a tudomány számára hibás közlési módja miatt használhatatlan anyagot nyújt”. ${ }^{37}$ A szerkesztőség feladatának tartja az adatközlés folyamán a szakmai felkészültség előtérbe helyezését és a szövegek közlési módjára és jegyzeteire vonatkozóan a filológiai pontosságot.

\section{A FELVILÁGOSODÁS KORA MAGYAR IRODALMÁRA VONATKOZÓ IRODALOMTÖRTÉNET-ÍRÁS}

„[...] 1945 szeptemberében megalakult Bolyai Tudományegyetemen a Magyar Irodalomtörténeti Intézethez két professzort neveztek ki, György Lajost és Jancsó Elemért. György Lajos ezúttal az egyetem prorektora, Jancsó Elemér pedig a Bölcsészeti Kar dékánja volt”. ${ }^{38} 1949$ 1959 közötti tíz évben, vagyis a V. Babeş és a Bolyai Tudományegyetem egyesítéséig a magyar irodalomtörténeti tanszék létszáma 10-15 fő között ingadozott. Jancsó Elemér a felvilágosodás korának volt előadótanára, de tanította a 20. század magyar irodalmát is nyolc éven keresztül.

Jancsó Elemér felvilágosodás korszakára vonatkozó kutatásainak két fó iránya van: az egyik az erdélyi felvilágosodás ismeretlen vagy kevésbé ismert problematikájának dokumentumait feldolgozó és kiadás alá szerkesztő tevékenysége, a másik területe a felvilágosodás íróinak (Batsányi János, Csokonai Vitéz Mihály, Kazinczy Ferenc, Aranka György, Bölöni Farkas Sándor) válogatott mûveinek kiadása bevezető tanulmányokkal. A felvilágosodás korszakára vonatkozó kutatásainak jelentősége, hogy a forráskiadásokon túlmenően - és ebben érhetjük tetten kontinuitását a pozitivista irodalomtörténeti hagyománnyal - kiterjeszti a korszakkutatást a társadalmi tényezők vizsgálata felé. Kutatásai középpontjába kerül az író és olvasó viszonya, a könyvkiadás, a könyvterjesztés, az írói hivatástudat és írói sorskérdés, az eszmék és programok intézményes formái (Erdélyi Magyar Nyelvművelő Társaság, Kolozsvári Színház, a Döbrentei által 1814-1818 között szerkesztett Erdélyi Múzeum), a szabadkő-

35 Jancsó Elemér: Ápoljuk nagyobb gonddal haladó hagyományainkat. Utunk IX(1954). 9. sz.

36 Jancsó Elemér: Haladó irodalmi hagyományaink ápolásáért. Utunk X(1955). 44. sz.

37 Uo.

38 Uó: Kortársaim. Tanulmányok, cikkek, portrék, birálatok 1928-1971. S.a.r. Mózes Huba. Kriterion, Buk., 1976. 203. 
művesség művelődéstörténeti jelentősége, de az egyes műfajok (napló- és emlékirat-irodalom, költői levelezések) társadalomtörténeti szempontok szerinti értékelése is.

Jancsó a felvilágosodásra vonatkozó korszak kutatásait egyrészt a forrásokhoz való közeledéssel kezdi, azaz az erdélyi felvilágosodás ismeretlen vagy kevésbé ismert problémáinak a dokumentumanyagát tárja fel (olyan művekre gondolok többek között, mint pl. az Erdélyi Magyar Nyelvművelő Társaság iratainak sajtó alá rendezése vagy a már korábban indult törekvése, az Irodalmi ritkaságok sorozat szerkesztése, sajtó alá rendezése), másrészt elkezdi sajtó alá rendezni a felvilágosodás korának nagyjait (Batsányi, Csokonai, Kazinczy), azok válogatott múveit bevezetőkkel. A felvilágosodás korának irodalomtörténetével foglalkozó munkákban különleges jelentőséget azoknak tulajdonít, amelyek a magyar irodalom világirodalmi, elsősorban a szomszéd népekkel való kapcsolatokat vizsgálták.

A kutatások módszerének megváltozását olvashatjuk ki az irodalomtörténet-írásra vonatkozó diskurzusból. Míg a polgári irodalomtörténet-írás a kölcsönhatásokat hangsúlyozza, a marxista tudósok főleg a közép- és kelet-európai irodalmaknak a magyar irodalommal való kapcsolatait tárgyalva a párhuzamosságokat vizsgálták. Jancsó szerint úgy mutattak rá a párhuzamosságokra, hogy nem hanyagolták el a kölcsönhatásokat sem.

\section{ZÁRSZÓ}

A dolgozatban felvetett kérdések megválaszolása jelen dolgozatban nem zárult le, a cél mégis megvalósult, hiszen sikerült ráirányítani a figyelmet a kérdéskör komplexitására. A jelenség kutatásának aktualitását adja az a tény is, hogy ha végignézzük a rendszerváltás után keletkezett magyar irodalomtörténeteket, akkor azt tapasztaljuk, hogy az erdélyi irodalom-magyar irodalom vagy magyar irodalom Erdélyben kérdésköre még mindig nem tisztázott a maga teljességében, hiszen megírták már $A$ magyar irodalom történeteit, a Magyar irodalmat ${ }^{39}, A$ magyar irodalom Erdélyben $I-V I{ }^{40}$ korszakos jelentőségű múveket, és amint látjuk a címekből is, valamiféle elkülönülés, elkülönítés, megkülönböztetés az erdélyi és a magyar irodalom tekintetében még mindig jelen van. A kérdés kifejtése során azt érdemes vizsgálni, hogy az egyes korszakokra vonatkozó, de Erdélyben, erdélyi szerző tollából származott, a magyar irodalomtörténet egészére vonatkozó szakirodalmak, tudományos munkák hogyan kerülnek fölhasználásra a mai irodalomtörténeti kézikönyveinkben a korszak fejezetének a megírásakor, vagy az egyes szerzők életmûvének a bemutatásakor történik-e hivatkozás erre vonatkozóan. Elgondolkodtató a tény, hogy hogyan kezeli a határon túli irodalomtörténet, határon túli irodalom kérdését például $A$ magyar irodalom történetei korszakos jelentőségű, egyik legújabb irodalomtörténeti kézikönyvünk. „A magyar irodalom történetei néhány fejezetében a mai államhatárokon túli irodalommal is foglalkozik. Ennek a területnek a megítélése azért nehéz, mert az erdélyi, felföldi, délvidéki vagy akár nyugati magyar irodalom múvelőire is vonatkozik

39 Magyar irodalom. Szerk. Gintui Tibor. Akadémiai, Bp., 2010.

40 Pomogáts Béla: Magyar irodalom Erdélyben. Irodalmi dokumentumok I-VI. Pallas Akadémia, Csíkszereda, 2008-2010. 
az a szomorú igazság, amelyet Belting így összegezett: „A szórvány nem a saját területén él, és reménytelenül keresi saját azonosságát” (Belting 2003, 73). ${ }^{41}$

\section{LITERARY HISTORY AND IDEOLOGY IN TRANSYLVANIA BETWEEN 1918 AND 1964}

\section{Keywords: Transylvanian scientific activity, Transylvanian literary history, erudite life-works}

Based on the life-work of Elemér Jancsó, a literature-historian from Transylvania, the study analyzes the research history of the literature from Transylvania between 1919 and 1969. Jancsó was a prominent figure of the period of the rearrangements following the World War I, he shared the identity-seeking endeavours of the 1930s, as well as the Transylvanian academic efforts following 1944. Between 1945 and 1947 he was a teacher at the Department of Hungarian Literary Studies of the Bolyai University from Cluj, since February 1947 he had been dean of the Faculty of Letters and director of the Institute of the Hungarian Literature-history. From the summer of 1948 he edited the textbooks for Hungarian literature together with Gyula Csehi and Gábor Gaál. Between 1945 and 1949 he taught modern literature, between 1949 and 1959 the literature-history of the Enlightenment, and for eight years the Hungarian literature of the $20^{\text {th }}$ century. In 1969 he edited The Hungarian Literature in the Enlightenment, a textbook addressed to his students.

Our paper studies the methodology of the literature-history writing through the life-work of Jancsó from the 1930' and afterwards, because starting from 1945 the "building of the socialism" and the "cultural revolution" rewrote both the methodology of the literature-history writing and the teaching practice of the history of the literature.

\section{ISTORIA LITERARĂ ȘI IDEOLOGIE ÎN TRANSLVANIA ÎNTRE 1918 ȘI 1964}

\section{Cuvinte-cheie: activitatea științifică din Transilvania, istoriile literare transilvănene, biografii de savanţi}

Studiul analizează prin opera istoricului literar Elemér Jancsó cercetările literare din Transilvania în perioada 1919-1969. Jancsó a participat în mod activ la reorganizările de după primul război mondial, la orientările generațiilor în anii 1930 și la eforturile științifice din Transilvania începând cu 1944 până la moarte (1971). A lucrat ca profesor la catedra de maghiară la Universitatea Bolyai (1945-1947), începând cu februarie 1947 fiind decanul Facultății de Litere și șeful Institutului de Literatura Maghiară. Din vara anului 1948 a participat cu Gyula Csehi și Gábor Gaal la redactarea manualelor de literatura maghiară. Între 1945-1949 a predat literatura modernă, din 1949 până în 1959 istoria literaturii din timpul Iluminismului, şi timp de opt ani literatura din Ungaria în sec. al XX-lea. În 1969 îşi publică cursul universitar intitulat $A$ magyar irodalom a felvilágosodás korában [Literatura maghiară din timpul Iluminismului]. Studiul analizează metodologia istoriei literare în opera lui Jancsó la mijlocul anilor 1930 precum şi mai târziu, deoarece din 1945, sub sloganul ,înfăptuirii comunismului” şi a „revoluţiei culturale”, întreaga metodologie a scrierii istoriei literare și a predării literaturii au fost reformulate pe baza directivelor centrale.

41 A magyar irodalom történetei. Főszerk. Szegedy-Maszák Mihály. Gondolat, Bp., 2008. 16. 